\title{
Biopsy of Peritoneum
}

National Cancer Institute

\section{Source}

National Cancer Institute. Biopsy of Peritoneum. NCI Thesaurus. Code C51627.

Removal of tissue from the peritoneum for microscopic examination. 